\title{
Identification of perylene in sediments: Occurrence and diagenetic evolution
}

\author{
${ }^{1}$ K. Opuene, ${ }^{2 *}$ I. E. Agbozu, ${ }^{3}$ C. C. Iwuozor \\ ${ }^{1}$ Department of Pure and Industrial Chemistry, University of Nigeria, Nsukka, Enugu State, Nigeria \\ ${ }^{2}$ Department of Pure and Applied Chemistry, Niger Delta University, P.M.B. 71, Yenagoa, Nigeria \\ ${ }^{3}$ Department of Environmental Sciences, Faculty of Engineering and Environmental Sciences, \\ Imo State University, Owerri, Nigeria \\ Received 3 May 2007; $\quad$ revised 12 June 2007; $\quad$ accepted 15 August 2007; $\quad$ available online 1 September
}

\begin{abstract}
Perylene and penta-aromatic hydrocarbons were determined in sediments as part of a study that was dedicated to the aquatic ecosystem of Elelenwo Creek (Southern Nigeria) in order to carry out a critical corroboration of occurrence and diagenetic evolution of perylene in the sediments of the creek. The results show that the annual mean levels of Benzo [g, h, i] Perylene ranged from $209.00-245.28 \mu \mathrm{g} / \mathrm{kg}$ dry weight at the various stations sampled. Meanwhile, Station 3 recorded the highest mean level of $245.28 \mu \mathrm{g} / \mathrm{kg}$ dry weight. The observed values for total penta-aromatic hydrocarbons were high $(787.00-1154.36 \mu \mathrm{g} / \mathrm{kg}$ dry weight) in all the stations sampled. In addition, the highest mean value of $1154.36 \mu \mathrm{g} / \mathrm{kg}$ dry weight was again recorded at station 3 for the penta-aromatic hydrocarbons. One origin index or concentration ratio of Ip/Ip+BghiP was also used to evaluate the suitability of the penta-aromatic hydrocarbons as a tracer to distinguish between contaminations arising from different sources. The values for the sampling stations therefore ranged from 0.41 to 0.43 . A critical appraisal of the PAH index, consequently, suggested that petroleum combustion is the major penta-aromatic hydrocarbon source in sediments of the creek. The PAH group profile shows that perylene was high in the sediments and would pose apparent effects in fauna. The high concentration of perylene in the sediments was also indicative of an in situ biogenic derivation. Furthermore, a concentration of perylene $>10 \%$ of total penta-aromatic hydrocarbons established a credible diagenetic origin.
\end{abstract}

Key words: Elelenwo Creek, perylene, penta-aromatic hydrocarbons, sediments

\section{INTRODUCTION}

The present study is part of a study that was dedicated to the aquatic ecosystem of Elelenwo Creek. This tidal and brackish creek, which is situated around Elelenwo area in the Obio-Akpor Local Government Area of Rivers State of Southern Nigeria passes through Atani and Elimbu Districts and connects Okrika river, receives abattoir, urban, and poultry wastes, etc. The study area enjoys the humid tropical climate, which was characterized by the hot and wet conditions derived from the movement of the Inter-Tropical Convergence Zone (ITCZ) north and south of the equator and experiences consistently high temperatures (about $34^{\circ} \mathrm{C}$ ) all year round. Since temperature varies only

ه*Corresponding Author Email: iwekumo@yahoo.co.uk Tel./Fax: +234 8035426708 slightly, rainfall distribution, over space and time, becomes a single most important factor. The implication is that there is a prolonged rainy season in the area.

The study area, therefore, has two major seasons, the dry season and the wet season (Okafor and Opuene, 2006). Benzo [g, h, i] perylene simply referred to as perylene may result from both organic matter diagenesis and anthropogenic processes (Simoneit, 1977; LaFlamme and Hites, 1978; Wakeham, et al., 1980). However, the diagenetic contribution usually outweighs the inputs from other sources, and is responsible for the general increase over the last 100 years (Hites, et al., 1977). Due to trade and industry in the area, Elelenwo Creek appears to be a receptor of organic pollutants. 
Furthermore, information regarding the local pollution level of the creek and its effects is limited. And considering the physical state of the aquatic ecosystem, it seems necessary to conduct an assessment of perylene, which has no known commercial production or use, in sediments so as to establish its occurrence and diagenetic evolution in the creek.

Sediments in general have been used to examine the pollution of aquatic environments for the reason that perylene and the pent a aromatics (as polycyclic aromatic hydrocarbons-PAHs) generally existing in low concentrations in the water column have a propensity to associate preferentially with the sediments to attain considerable concentration levels (Xiao-Jun, et al., 2006).

In addition, the transport and fate of these classes of PAHs in aquatic ecosystems have received some attention in Southern Nigeria because of concerns over accumulation (Okafor and Opuene, 2007). Benzo [g, h, i] perylene, also known as 1,12-benzoperylene, is a polycyclic aromatic hydrocarbon $(\mathrm{PAH})$ with six aromatic rings. It is a crystalline solid with an estimated log octanol/water partition coefficient of 7.04-7.10 and is practically insoluble in water but is soluble in 1,4-dioxane, dichloromethane, benzene, and acetone (EPA, 1987).

Its absorption data is not available; however, by analogy to other PAHs, primarily benzo [a] pyrene, it would be expected to be absorbed from the gastrointestinal tract, lungs, and skin of fauna in sediments of aquatic ecosystems with potential for impacts (EPA, 1991).

For the reason that perylene in the environment is attracting increasing attention for its widespread occurrence and potential impacts such as mutagenic, carcinogenic, and teratogenic effects (Freitag, et al., 1985) coupled with some synergism in effect in the presence of benzo [a] pyrene in aquatic fauna (Van Duuren, et al., 1973), the goal of this study was to apply perylene over pentaaromatic isomers as a molecular tool to explicate the occurrence and diagenetic derivation of perylene in the sediments of Elelenwo Creek, Southern Nigeria.

Table 1: Geo-referencing of sampling sites and description of sediment samples

\begin{tabular}{lllll}
\hline Station & $\begin{array}{l}\text { Longitude } \\
(\mathrm{E})\end{array}$ & $\begin{array}{l}\text { Latitude } \\
(\mathrm{N})\end{array}$ & Mean TOC (\%) & Sediment \\
\hline 1 & $007^{\mathrm{O}} 04^{\mathrm{I}} 00.8^{\mathrm{II}}$ & $04^{\mathrm{O}} 49^{\mathrm{I}} 32.0^{\mathrm{II}}$ & 1.02 & Sescription \\
2 & $007^{\mathrm{O}} 03^{\mathrm{I}} 56.7^{\mathrm{II}}$ & $04^{\mathrm{O}} 49^{\mathrm{I}} 37.7^{\mathrm{II}}$ & 1.10 & Silt \\
3 & $007^{\mathrm{O}} 04^{\mathrm{I}} 00.3^{\mathrm{II}}$ & $04^{\mathrm{O}} 49^{\mathrm{I}} 40.0^{\mathrm{II}}$ & 1.37 & Silt \\
4 & $007^{\mathrm{O}} 03^{\mathrm{I}} 56.6^{\mathrm{II}}$ & $04^{\mathrm{O}} 49^{\mathrm{I}} 40.1^{\mathrm{II}}$ & 1.29 & Silt \\
5 & $007^{\mathrm{O}} 04^{\mathrm{I}} 04.1^{\mathrm{II}}$ & $04^{\mathrm{O}} 49^{\mathrm{I}} 37.5^{\mathrm{II}}$ & 1.49 & Silt \\
\hline
\end{tabular}

Table 2: Mean concentration of PAHs in sediment samples $(\mu \mathrm{g} / \mathrm{kg})$

\begin{tabular}{llllll}
\hline \multirow{2}{*}{ Parameter } & \multicolumn{5}{c}{ Sampling site } \\
& \multicolumn{1}{c}{1} & \multicolumn{1}{c}{3} & 3 & 4 & 519.60 \\
\hline Benzo [b] Fluoranthene & 352.00 & 394.24 & 507.36 & 484.96 & 195.60 \\
Benzo [k] Fluoranthene & 152.00 & 170.24 & 204.96 & 182.68 & 346.80 \\
Benzo [a] Pyrene & 214.00 & 239.68 & 351.68 & 323.68 & 81.60 \\
Dibenzo [a, h] Anthracene & 68.00 & 76.16 & 87.36 & 76.16 & 240.00 \\
Benzo [g, h, i] Perylene & 209.00 & 234.08 & 245.28 & 224.00 & 187.04 \\
Indeno [1, 2, 3-cd] Pyrene & 155.87 & 146.30 & 198.99 & 66.10 & 1148.6 \\
Total 5-Ring PAHs & 787 & 882.32 & 1154.36 & 1071.48 & 114.86 \\
10\% of 5-Ring PAHs & 78.7 & 88.23 & 115.43 & 107.15 & 39.92 \\
\% Perylene over 5-Ring PAHs & 49.76 & 49.76 & 41.24 & 39.92 & \\
\hline
\end{tabular}




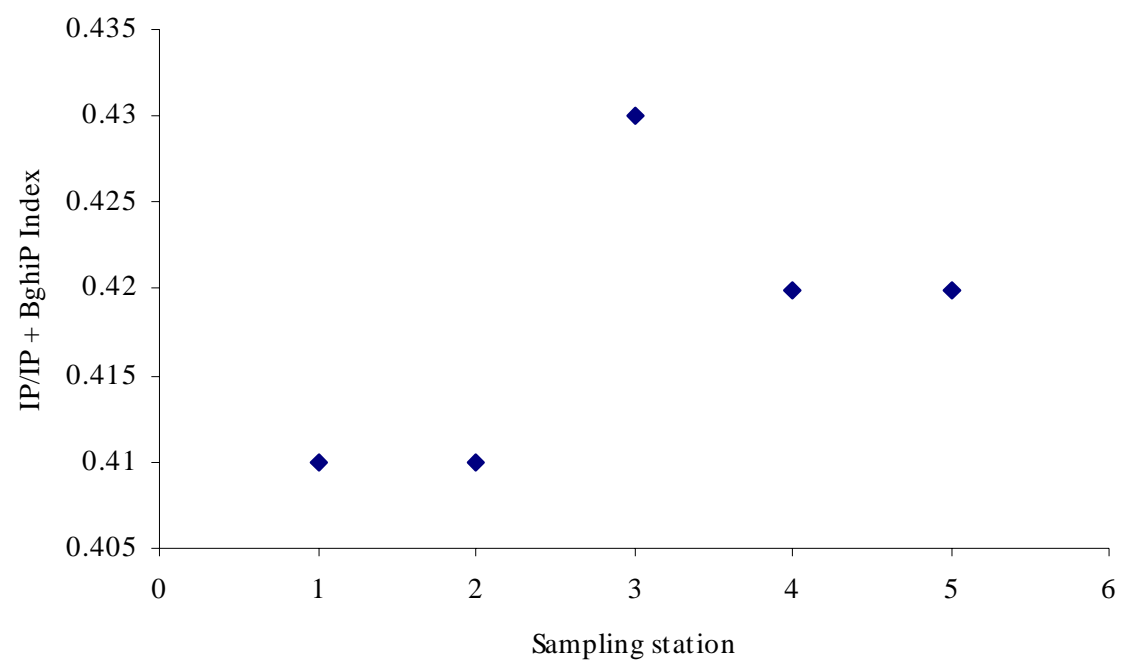

Fig. 1: Scatter plot of PAH compositional indices Vs Sampling stations

\section{MATERIALS AND METHODS}

Five sampling stations were selected in the current study. Surficial sediment was sampled using a stainless steel grab sampler for the period February 2006 to February 2007.

The sediment samples $(0-20 \mathrm{~cm}$ depth) were scooped into pre-cleaned amber glass bottles and properly cooled in a refrigerator $\left(4^{\circ} \mathrm{C}\right)$ until they were stored at $-20{ }^{\circ} \mathrm{C}$ pending further treatment After removing coarse materials $(>2.5 \mathrm{~mm})$, the sediments were freeze dried at $-50{ }^{\circ} \mathrm{C}$ and stored in dark bottles. The sediments were Soxhlet extracted for $8 \mathrm{~h}$ in a cellulose thimble with dichloromethane. The extracts were further purified to avoid interferences by aliphatic hydrocarbons, porphrins, chlorins, and carotenoids, if present in the prepared matrices. The empirical purification entailed the use of neutral activity I alumina as an adsorbent. It was introduced in slurry form with hexane into $1 \mathrm{~cm}$ glass columns to a depth of about $10 \mathrm{~cm}$. Concentrated extracts were dissolved in hexane and subsequently introduced to the wet adsorbent and eluted with hexane to remove aliphatic hydrocarbons. A second eluant was benzene, which removed the aromatic components with sufficient purity for the Capillary Gas Chromatographic analysis (Okafor and Opuene, 2007). The purified aromatics were analyzed by capillary gas chromatography using an HP 6890 Series GC system equipped with a flame ionization detector (FID). The column used was a HP-5, 30 m X 0.25 mm X 0.25 mm (HP Part No. 19091S-433). Hydrogen (10.2 psi) was used as carrier gas at $1.5 \mathrm{~mL} / \mathrm{min}$. The column was kept at $80^{\circ} \mathrm{C}$ for $1 \mathrm{~min}$. It was programmed to $280^{\circ} \mathrm{C}$ at the rate of 20 ${ }^{\circ} \mathrm{C} / \mathrm{min}$. The column temperature was further programmed to a final hold at $300^{\circ} \mathrm{C}$ at the rate of $2.5^{\circ} \mathrm{C} / \mathrm{min}$. Temperature of the FID and $\mathrm{T}_{\mathrm{ij}}(1 \mathrm{~mL}$, $0.01 \mathrm{mg}$ each $/ \mathrm{ml}$, split $25 / 1$ ) were kept at $325^{\circ} \mathrm{C}$. Subsamples of sediments were acidified to remove carbonates and the levels of total organic carbon (TOC) were determined using a CHNS Vario El III analyser.

The limit of detection was $0.01 \mu \mathrm{g} / \mathrm{g}$ for the various PAHs studied. And in carrying out recovery analyses, a perdeuterated PAH (perylene- $d_{12}$ ) was added to samples prior to extraction to quantify procedural efficiency. The surrogate recovery was $90.76 \pm 10.53 \%$ for perylene- $d_{12}$. Data analysis included calculating individual and total $\mathrm{PAH}$ concentrations, and summarizing PAH compositional indices or ratios. The PAH compositional index or ratio used in the assessment incorporated Indeno [1, 2, 3-cd] Pyrene/ Indeno [1, 2, 3-cd] Pyrene + Benzo [g, h, i] Perylene (Ip/Ip+BghiP). A linear regression analysis was carried out for perylene and TOC using Analysis Toolpak Software (Zar, 1990). 


\section{RESULTS}

The results of the annual mean levels for the PAHs are presented in Table 2. The results show that the annual mean levels of Benzo [g, h, i] Perylene ranged from $209.00-245.28 \mathrm{mg} / \mathrm{kg}$ dry weight at the various stations sampled. In the interim, Station 3 recorded the highest mean level of $245.28 \mathrm{mg} / \mathrm{kg}$ dry weight. The observed values for total penta-aromatic hydrocarbons were high (787.00 - $1154.36 \mathrm{mg} / \mathrm{kg}$ dry weight) in all the stations sampled. However, the highest mean value of $1154.36 \mathrm{mg} / \mathrm{kg}$ dry weight was again recorded at station 3. PAH compositional index or ratio of Ip/ Ip+BghiP for the sampling stations ranged from 0.41 to 0.43 . A linear regression analysis for perylene and TOC was highly significant $\left(r^{2}=0.923\right)$.

\section{DISCUSSION AND CONCLUSION}

Perylene concentrations in sediments were higher in site 3 than in the other sampling sites (Table 2). Highest penta-aromatic concentrations were detected in sediments from stations 3 and 5 respectively. Higher penta-aromatic concentrations in sites 3 and 5 could be attributed to preferential retaining of the PAHs by high TOC in the sediments at sites 3 and 5 relative to sites 1, 2 and 4 . However, decreasing interaction of the penta-aromatics with sediments may have resulted in lower concentrations in sites 1,2 and 4 respectively. The total PAH concentrations in the sediments were noted to be higher than the sediment $\mathrm{PAH}$ concentrations of Taylor Creek, Southern Nigeria (Okafor and Opuene, 2007).

A significant factor that controls the concentration of PAHs in sediment is TOC (XiaoJun, et al., 2006). A positive correlation in particleassociated PAH concentration with TOC has been found in many aquatic ecosystems, such as the Pearl River Estuary (Xiao-Jun, et al., 2006). In this study, the effect of TOC on the PAH concentrations was also studied. A linear regression analysis showed that the total concentrations of the PAHs in the sediments was correlated to the organic carbon content with $\mathrm{r}^{2}=0.923$, which indicated that TOC influenced the distribution of PAHs in the sediments. The net implication is that the concentration levels of the PAHs are in excess of the Overall Apparent Effects Threshold of Long and Morgan (1990) and may be mutagenic and carcinogenic to fauna (Okafor and Opuene, 2007). $\mathrm{PAH}$ isomer pair ratio such as Ip/Ip+BghiP has been used as distinct chemical tracer to infer possible sources of PAHs in environmental samples (Yunker, et al., 2002). Based on the PAH isomer pair ratio measurements compiled by Prahl and Carpenter (1983), a ratio of Ip/Ip+BghiP $<0.2$ indicates petroleum, 0.2 to 0.5 indicate petroleum combustion, and $>0.5$ indicates combustion of coal, grass and wood. The ratio of $\mathrm{Ip} / \mathrm{Ip}+\mathrm{BghiP}$ shows that the penta-aromatics are from petroleum combustion (Fig. 1).

In addition, perylene has been found widely in a variety of marine, riverine sediments and peats (Jiang, et al., 2000). It is a diagenetic product derived from its natural precursors during early diagenesis (Venkatesan, 1988). Only trace amounts of perylene are produced during combustion. A concentration of perylene $>10 \%$ of total pentaaromatic hydrocarbons has been suggested to indicate a probable diagenetic input; or else a probable pyrolytic origin is indicated (Baumard, et al., 1998). Nonetheless, Tolosa, et al. (2004) found that a less than $20 \%$ of perylene over pentaaromatic isomers indicated a typical pyrolytic source of this compound. Elevated concentrations (from 209.00 to $245.28 \mu \mathrm{g} / \mathrm{kg}$ dry weight) of perylene relative to the other PAH compounds in sediment samples were obtained in this study. Percentages of perylene over the penta-aromatic isomers varied from $39.92 \%$ to $49.76 \%$ in sediment samples (Table 2 ), which was indicative of an in situ biogenic origin.

\section{REFERENCES}

Baumard, P.; Budszinski, H.; Mchin, Q.; Garrigues, P.; Burgeot, T.; Bellocq, J., (1998). Origin and bioavailability of PAHs in the Mediterranean Sea from mussel and sediment records. Estuar., Coast. Shelf Sci., 47, 77- 90.

Cerniglia, C.E., (1992). Biodegradation of polycyclic aromatic hydrocarbons. Biodegradation, 3, 351-368.

Countway, R.E.; Dickhut, R.M.; Canuel, E.A., (2003). Polycyclic aromatic hydrocarbon (PAH) distributions and associations with organic matter in surface waters of the York River, VA Estuary. Org. Geochem., 3, 351-368.

EPA, (1987). Health and Environmental Effects Profile for Benzo (ghi) perylene. Prepared by the Environmental Criteria and Assessment Office, Office of Health and Environmental 
Assessment for the Office of Solid Waste and Emergency Response, Cincinnati, OH. ECAO-CIN-P276.

EPA, (1991). Drinking Water Criteria Document for Polycyclic Aromatic Hydrocarbons (PAHs). Prepared by the Environmental Criteria and Assessment Office, Office of Health and Environmental Assessment, U.S. Environmental Protection Agency, Cincinnati, $\mathrm{OH}$, for the Office of Drinking Water. ECAO-CIND0 010 .

Freitag, D.; L. Ballhorn, H.; Geyer, Korte, F., (1985). Environmental hazard profile of organic chemicals. Chemosphere, 14, 1589-1616.

Harvey, R.G., (1996). Polycyclic Aromatic Hydrocarbons, Wiley, New York, 8-11

Hites, R.A., Laflame, R.E., Farrington, J.W., (1997). Sedimentary polycyclic aromatic Hydrocarbonshistorical record. Science, 198, 829-831.

Jiang, C.Q.; Robert, A.; Robert, I.K.; Andrew, P.M., (2000). Origin of perylene in ancient sediments and its geological significance. Org. Geochem., 31, 1545-1559.

LaFlamme, R.E.; Hites., R.A., (1978). The global distribution of polycyclic aromatic hydrocarbons in Recent sediments. Geochim. Cosmochim. Ac., 42, 289303.

Meglen, R.R., (1992). Examining large databases: a chemometric approach using principal component analysis. Mar. Chem., 39, 217-237.

McVeety, B.D.; Hites, R.A., (1988). Atmospheric deposition of polycyclic aromatic hydrocarbons on water surfaces: A mass balance approach. Atmos. Environ., 22: 511-536.

Okafor, E.C.; Opuene, K., (2006). Correlations, partitioning and bioaccumulation of trace metals between different segments of Taylor Creek, southern Nigeria. Int. J. Environ. Sci. Tech., 3(4), 437-445.

Okafor, E.C.; Opuene, K., (2007) Preliminary assessment of trace metals and polycyclic aromatic hydrocarbons in the sediments of Taylor Creek, Southern Nigeria. Int. J. Environ. Sci. Tech., 4(2), 233-240.

Prahl, F.G.; Carpenter, R., (1983). Polycyclic aromatic hydrocarbon (PAH) -Phase association in Washington coastal sedimentary particulates from Dadob Bay, Washington D.C., Geochim. Cosmochim. Ac., 47, 463472 .

Simoneit, B.R.T., (1977). Diterpenoid compounds and other lipids in deep-sea sediments and their geochemical significance. Geochim. Cosmochim. Ac., 41, 463-476.

Tolosa, I.; de Mora, S.; Sheikholeslami, M.R., Villeneuve, J.P., Bartocci, J., Cattini, C., (2004) Aliphatic and aromatic hydrocarbons in coastal Caspian Sea sediments. Mar. Pollut. Bull., 48, 44-60.

Wakeham, S.G.. Schaffiner, C.. Giger, W., (1980). Polycyclic aromatic hydrocarbons in recent lake sediments II: Compounds derived from biogenic precursors during early diagenesis. Geochem. Cosmochim. Ac., 44, 415-429.

Xiao-Jun, L.; She-Jun, C.; Bi-Xian, M.; Qing-Shu, Y.; GuoYing, S.; Jia-Mo, F., (2006). Polycyclic aromatics hydrocarbons in suspended particulate matter and sediments from the Pearl River Estuary and adjacent areas, China. Environ. Pollut., 139, 9-20.

Venkatesan, M.I., (1988). Occurrence and possible sources of perylene in marine: a review. Mar. Chem., 25, 1-27.

Witt, G., (1995). Polycyclic aromatic hydrocarbons in water and sediments of the Baltic Sea. Mar. Pollut. Bull., 31, 1139-1149.

Young, L.Y.; Cerniglia, C.E., (1995). Microbial transformation and degradation of Toxic Organic Chemicals. Wiley, New York

Yunker, M.B.; Macdonald, R.W.; Vingazan, R.; Mitchell, R.H.; Goyette, D.; Sylvestre, S., (2002). PAHs in the Fraiser River Basin: a critical appraisal of PAHs ratios as indicators of $\mathrm{PAH}$ source and composition. Org. Geochem., 33, 489-515.

Zar, J.H., (1996). Biostatistical analysis. Prentice-Hall, upper Saddle River, 662.

Zhou, J.L.; Maskaoui, K., (2003). Distribution of polycyclic aromatic hydrocarbons in water and sediments from DaYa Bay, China. Environ. Pollut., 121, 269-281. 
K., Opuene, et al.

\section{AUTHOR (S) BIOSKETCHES}

Opuene, K., Ph.D., Department of Pure and Industrial Chemistry, University of Nigeria, Nsukka, Nigeria. Emain: opuenekings@yahoo.com

Agbozu, I. E., Ph.D., lecturer in the Department of Pure and Applied Chemistry, Niger Delta University Wilberforce Island P.M.B. 71 Yenagoa, Nigeria.Email: iwekumo@yahoo.co.uk

Ekeh, L.E., M.Phil, M.Sc., student in the Department of Environmental Sciences, Faculty of Engineering and Environmental Sciences, Imo State University, Owerri, Nigeria.

Email: adakuekeh@yahoo.co.uk

This article should be referenced as follows:

Opuene, K.; Agbozu, I. E., Ekeh; L.E., (2007). Identification of perylene in sediments: Occurrence and diagenetic evolution. Int. J. Environ. Sci. Tech., 4 (4), 457-462. 